Florida International University FIU Digital Commons

4-12-2016

\title{
Rescuing Our Roots: The African Anglo- Caribbean Diaspora in Contemporary Cuba
}

Cuban Research Institute, Florida International University

Follow this and additional works at: https://digitalcommons.fiu.edu/cri_events

Part of the Latin American Studies Commons

\section{Recommended Citation}

Cuban Research Institute, Florida International University, "Rescuing Our Roots: The African Anglo-Caribbean Diaspora in Contemporary Cuba" (2016). Cuban Research Institute Events. 267.

https://digitalcommons.fiu.edu/cri_events/267 


\title{
The Green School at Books \& Books
}

\section{Cuban Research Institute}

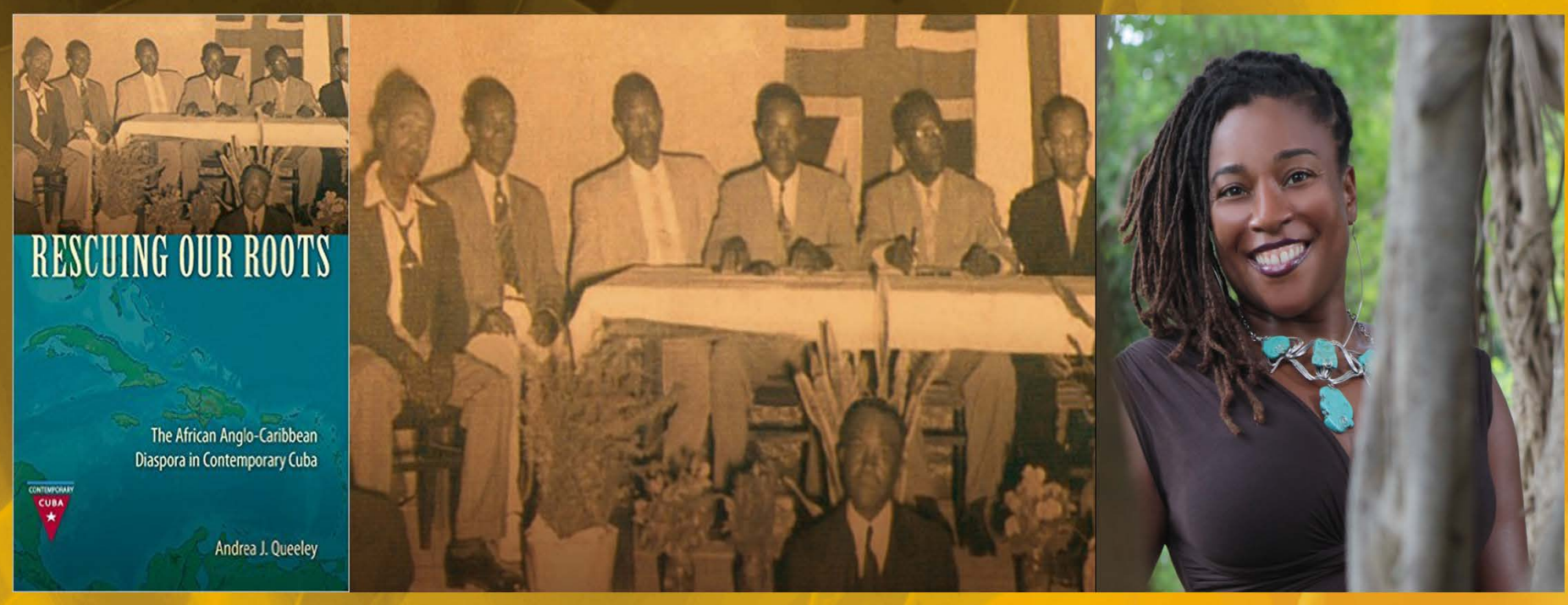

\section{Rescuing Our Roots:}

\section{The African Anglo-Caribbean Diaspora in Contemporary Cuba}

\author{
Book Presentation by Author Andrea J. Queeley
}

Tuesday, April 12, 2016 | 8:00 PM | Books \& Books, 265 Aragon Ave., Coral Gables

During Cuba's Special Period, the children and grandchildren of early 20th-century British West Indian immigrants spearheaded the revitalization of Anglo-Caribbean Cuban institutions and community. This book turns an ethnographic lens onto those black Cubans in Santiago and Guantánamo who moved to "rescue the roots" nearly 70 years after the bulk of immigrants arrived in Cuba, providing insight into local and regional identity formations that can emerge from intra-Caribbean migration as well as into racial politics in revolutionary Cuba. Engaging scholarship on diaspora and black subject formation, this examination of a diaspora within a diaspora provides a window into strategies and modes of black belonging that shift across time, space, and place.

Andrea Queeley is a cultural anthropologist and associate professor in the Department of Global and Sociocultural Studies and the African and African Diaspora Studies Program at Florida International University. She is also a Faculty Affiliate of the Cuban Research Institute at FIU. Her work contributes to a broader and interdisciplinary inquiry into how racialized subjects negotiate structural inequalities in contexts of political, economic, social, and environmental crisis. Based upon ethnographic research conducted in eastern Cuba, her book, Rescuing Our Roots: The African Anglo-Caribbean Diaspora in Contemporary Cuba, was published by the University Press of Florida in 2015.

This event is free and open to the public. To confirm your attendance and for more information, please call (305) 348-1991 or write cri@fiu.edu. 